\title{
Development of a decision flowchart to identify the patients need high-dose vancomycin in early phase of treatment
}

\author{
Ryo Yamaguchi ${ }^{1 \dagger}$, Hiroko Kani ${ }^{1 \dagger}$, Takehito Yamamoto ${ }^{1,2^{* \dagger}} \mathbb{D}$, Takehiro Tanaka ${ }^{1}$ and Hiroshi Suzuki ${ }^{1}$
}

\begin{abstract}
Background: The standard dose of vancomycin (VCM, 2 g/day) sometimes fails to achieve therapeutic concentration in patients with normal renal function. In this study, we aimed to identify factors to predict patients who require high-dose vancomycin ( $>2 \mathrm{~g} /$ day) to achieve a therapeutic concentration and to develop a decision flowchart to select these patients prior to VCM administration.

Methods: Patients who had an estimated creatinine clearance using the Cockcroft-Gault equation (eCCr) of $\geq 50$ $\mathrm{mL} / \mathrm{min}$ and received intravenous VCM were divided into 2 cohorts: an estimation set ( $n=146$, from April to September 2016) and a validation set ( $n=126$, from October 2016 to March 2017). In each set, patients requiring $\leq 2 \mathrm{~g} /$ day of VCM to maintain the therapeutic trough concentration $(10-20 \mu \mathrm{g} / \mathrm{mL})$ were defined as standard-dose patients, while those who needed $>2 \mathrm{~g} /$ day were defined as high-dose patients. Univariate and multivariate logistic regression analysis was performed to identify the predictive factors for high-dose patients and decision tree analysis was performed to develop decision flowchart to identify high-dose patients.

Results: Among the covariates analyzed, age and eCCr were identified as independent predictors for high-dose patients. Further, the decision tree analysis revealed that eCCr (cut off value $=81.3 \mathrm{~mL} / \mathrm{min}$ ) is the top predictive factor and is followed by age (cut off value $=58$ years). Based on these findings, a decision flowchart was constructed, in which patients with eCCr $\geq 81.3 \mathrm{~mL} / \mathrm{min}$ and age $<58$ years were designated as high-dose patients and other patients were designated as standard-dose patients. Subsequently, we applied this decision flowchart to the validation set and obtained good predictive performance (positive and negative predictive values are 77.6 and $84.4 \%$, respectively).
\end{abstract}

Conclusion: These results suggest that the decision flowchart constructed in this study provides an important contribution for avoiding underdosing of VCM in patients with eCCr of $\geq 50 \mathrm{~mL} / \mathrm{min}$.

Keywords: Vancomycin, Decision tree analysis, Decision flowchart, High dose, Creatinine clearance, MRSA infection

\footnotetext{
*Correspondence: takehitoyamamoto@g.ecc.u-tokyo.ac.jp

${ }^{\dagger}$ Ryo Yamaguchi, Hiroko Kani and Takehito Yamamoto contributed equally to this work.

'Department of Pharmacy, The University of Tokyo Hospital, Faculty of

Medicine, The University of Tokyo, 7-3-1 Hongo, Bunkyo-ku, Tokyo 113-8655,

Japan

${ }^{2}$ The Education Center for Clinical Pharmacy, Graduate School of

Pharmaceutical Sciences, The University of Tokyo, 7-3-1 Hongo, Bunkyo-ku,

Tokyo 113-0033, Japan
}

C C The Author(s). 2021 Open Access This article is licensed under a Creative Commons Attribution 4.0 International License, which permits use, sharing, adaptation, distribution and reproduction in any medium or format, as long as you give appropriate credit to the original author(s) and the source, provide a link to the Creative Commons licence, and indicate if changes were made. The images or other third party material in this article are included in the article's Creative Commons licence, unless indicated otherwise in a credit line to the material. If material is not included in the article's Creative Commons licence and your intended use is not permitted by statutory regulation or exceeds the permitted use, you will need to obtain permission directly from the copyright holder. To view a copy of this licence, visit http://creativecommons.org/licenses/by/4.0/ The Creative Commons Public Domain Dedication waiver (http://creativecommons.org/publicdomain/zero/1.0/) applies to the data made available in this article, unless otherwise stated in a credit line to the data. 


\section{Background}

Vancomycin (VCM) is a glycopeptide antibiotic that is widely used for the treatment of infections caused by methicillin-resistant Staphylococcus aureus (MRSA) [1]. Because numerous number of reports have shown that the ratio of the area under the drug concentration-time curve over $24 \mathrm{~h}\left(\mathrm{AUC}_{24}, \mu \mathrm{g} \cdot \mathrm{h} / \mathrm{mL}\right)$ to the minimum inhibitory concentration of pathogens $(\mathrm{MIC}, \mu \mathrm{g} / \mathrm{mL})$, hereafter referred to as $\mathrm{AUC}_{24} / \mathrm{MIC}$, is the best pharmacokinetic/pharmacodynamic (PK/PD) index to predict the clinical efficacy of VCM $[2,3]$, the latest Infectious Diseases Society of America (IDSA) guidelines [4] strongly recommends AUC-guided dosing to achieve an $\mathrm{AUC}_{24} / \mathrm{MIC}$ of $400-600$ in place of conventional trough concentration $\left(\mathrm{C}_{\text {trough }}\right)$-guided dosing. However, it is sometimes time and cost consuming process to calculate $\mathrm{AUC}_{24}$ because it requires multiple blood sampling and pharmacokinetic analysis using dedicated software. Therefore, numbers of researchers have investigated the relationship between $C_{\text {trough }}$ and $\mathrm{AUC}_{24}$ aiming to estimate $\mathrm{AUC}_{24}$ from single $\mathrm{C}_{\text {trough }}$. For instance, Clark et al. reported that $\mathrm{C}_{\text {trough }}$ of $12-18 \mu \mathrm{g} / \mathrm{mL}$ corresponded to $\mathrm{AUC}_{24}$ of $502-656 \mu \mathrm{g} \cdot \mathrm{h} / \mathrm{mL}$ [5]. Further, several researchers have shown that $C_{\text {trough }}$ of $>10 \mu \mathrm{g} / \mathrm{mL}$ was the significant predictive factor for $\mathrm{AUC}_{24}$ of $>$ $400 \mu \mathrm{g} \cdot \mathrm{h} / \mathrm{mL}$ in elderly patients [6, 7]. On the other hand, $\mathrm{C}_{\text {trough }}$ has also been extensively investigated as a predictor of nephrotoxicity of VCM, and Lodise et al. has reported that the risk of nephrotoxicity increases to $33 \%$ when the $\mathrm{C}_{\text {trough }}$ exceeds $20 \mu \mathrm{g} / \mathrm{mL}$ [8]. In addition, although several meta-analyses have investigated the superiority of AUC-guided dosing [9, 10], the most recent meta-analysis reported by Tsutsuura et al. [10] has not shown the superiority of AUC-guided dosing over $\mathrm{C}_{\text {trough-guided dosing in both effectiveness and safety }}$ due to the large 95\% confidential interval. Considering these reports, to achieve $C_{\text {trough }}$ of $10-20 \mu \mathrm{g} / \mathrm{mL}$ would maintain certain clinical significance in the era of AUCguided dosing.

Since more than $80 \%$ of intravenously administered VCM is excreted into the urine as unchanged form [11], the dosage of VCM should be individualized according to the renal function of the patient. Strategies for dosage adjustment of VCM in patients with impaired renal function, including patients on blood purification therapy, have been extensively investigated, and detailed dosing nomograms stratified by creatinine clearances $(\mathrm{CCr})$ are available [12]. Whereas for patients with $\mathrm{CCr}$ of $>50$ $\mathrm{mL} / \mathrm{min}, 2 \mathrm{~g} /$ day (i.e., $1 \mathrm{~g}$ every $12 \mathrm{~h}$ ), the standard dosage of VCM in package insert, is frequently selected as the initial dosage [13]. However, several studies recruiting critically ill patients or patients with heart failure have reported that augmented renal clearance (ARC), younger age, and sepsis status are the risk factors of subtherapeutic $C_{\text {trough }}$ even after administration of the standard dosage (2 g/day) [14-17]. Although these risk factors may be applicable to non-critically patients or patients without heart failure from the pharmacokinetic point of view, but there have been insufficient reports to support this. Patients' characteristics associated with subtherapeutic $\mathrm{C}_{\text {trough }}$ have also been explored using population PK (PPK) approach. Specifically, Yasuhara et al. have utilized population PK (PPK) approach and found that $\mathrm{C}_{\text {trough }}$ would be below $10 \mu \mathrm{g} / \mathrm{mL}$ in patients with normal renal function ( $\mathrm{CCr}>100-120 \mathrm{~mL} / \mathrm{min}$ ) even after administration of standard dose ( $1 \mathrm{~g}$ every 12 h) [18], though this estimation has not been in large population. Furthermore, Imai et al. applied a machine learning approach to determine optimal dosage for patients with estimated glomerular filtration rate (eGFR) of $\geq 50 \mathrm{~mL} / \mathrm{min} / 1.73 \mathrm{~m}^{2}$ using eGFR, age, and BMI as predictive factors [19]. However, validation analysis indicated that $\mathrm{C}_{\text {trough }}$ of $33.5 \%$ of patients expected to be < $10 \mu \mathrm{g} / \mathrm{mL}$. For other instance, Leu et al. proposed a dosing nomogram to achieve $C_{\text {trough }}$ of $15-20 \mu \mathrm{g} / \mathrm{mL}$ and recommended $3 \mathrm{~g} /$ day of VCM for patients whose $\mathrm{CCr}$ is $>70 \mathrm{~mL} / \mathrm{min}$ [20]. However, they also found that $C_{\text {trough }}$ exceeded $20 \mu \mathrm{g} / \mathrm{mL}$ in $23.5 \%$ of patients whose VCM dosages were adjusted using this nomogram. Thus, it is necessary to develop methods to predict more accurately which patients would require a higher dose of VCM ( $>2 \mathrm{~g} /$ day) to maintain the $\mathrm{C}_{\text {trough }}$ within the therapeutic range $(10-20 \mu \mathrm{g} / \mathrm{mL})$ in a patient population not limited to critically ill patients.

In this study, we aimed to identify the factors to predict patients with $\mathrm{CCr}$ of $\geq 50 \mathrm{~mL} / \mathrm{min}$ who require $>2 \mathrm{~g}$ / day of VCM and to determine cut-off values. We developed a simple decision flowchart based on those cut off values to identify the patients who required high-dose (> $2 \mathrm{~g}$ /day) of VCM from the beginning of treatment and evaluated its usefulness using data from a validation cohort.

\section{Methods}

\section{Study design and patients}

This retrospective, observational study was performed at the University of Tokyo Hospital (Tokyo, Japan), a tertiary care, teaching hospital with 1217 beds.

Patients who received intravenous VCM from April 2016 to March 2017 were enrolled in the study. We included patients whose $\mathrm{CCr}$ estimated using the Cockcroft-Gault equation (eCCr) [21] was $\geq 50 \mathrm{~mL} / \mathrm{min}$ immediately before VCM administration and whose steady state VCM $C_{\text {trough }}$ was measured at least once. The exclusion criteria were defined as follows: (A) patients under 18 years of age, (B) first $C_{\text {trough }}$ was measured within 2 days from the start of VCM administration $[18,22,23]$, (C) VCM dosage was 
changed before the first $C_{\text {trough }}$ measurement, and (D) renal function that fluctuated during VCM treatment. Fluctuation of renal function was defined as an increase in serum creatinine ( $\mathrm{SCr}$ ) by more than 1.5 -fold from baseline within 7 days or more than $0.3 \mathrm{mg} / \mathrm{dL}$ from baseline within $48 \mathrm{~h}$ after the start of VCM administration, according to the Kidney Disease: Improving Global Outcomes (KDIGO) guidelines [24].

Patients who received intravenous VCM from April 2016 to September 2016 were assigned to the estimation set, which was used to develop a decision flowchart. Patients who received intravenous VCM from October 2016 to March 2017 were assigned to the validation set, which was used to validate the decision flowchart.

\section{Data collection}

Age, sex, clinical department, body weight (BW), body mass index (BMI), SCr, initial VCM dosage, and VCM $\mathrm{C}_{\text {trough }}$ were extracted from patients' medical records. The eCCr was calculated using the Cockcroft-Gault equation (Eq. 1) based on the SCr measured immediately before the intravenous administration of VCM: [21].

$$
\begin{aligned}
\mathrm{eCCr}[\mathrm{mL} / \mathrm{min}]= & (140-\text { Age }[\text { years }]) \\
& \times \mathrm{BW}[\mathrm{kg}] /(72 \times \mathrm{SCr}[\mathrm{mg} / \mathrm{dL}])
\end{aligned}
$$

For female patients, the calculated value was multiplied by 0.85 .

Because previous reports have shown that eCCr calculated using Eq. 1 in obese patients overestimates the actual CCr [25, 26], the adjusted ideal body weight (AIBW) [27] was calculated using the following equation (Eq. 2), and BW in Eq. 1 was substituted by AIBW when calculating $\mathrm{eCCr}$ in patient whose BMI was $\geq 30 \mathrm{~kg} / \mathrm{m}^{2}$ : [26].

$$
\mathrm{AIBW}[\mathrm{kg}]=\mathrm{IBW}[\mathrm{kg}]+0.4 \times(\mathrm{BW}-\mathrm{IBW})
$$

where IBW represents the ideal BW calculated using the following equations (Eq. 3A, B):

$$
\begin{aligned}
\mathrm{IBW}(\text { Male })[\mathrm{kg}]= & 50.0+0.9 \\
\times & (\text { height }[\mathrm{cm}]-152.4) \\
\mathrm{IBW}(\text { Female) }[\mathrm{kg}]= & 45.5+0.9 \\
& \times(\text { height }[\mathrm{cm}]-152.4)
\end{aligned}
$$

\section{Definition of high-dose and standard-dose patients}

In this study, patients were classified into two patient groups, high-dose patients and standard-dose patients, based on the VCM dosages needed to maintain $\mathrm{C}_{\text {trough }}$ above $10 \mu \mathrm{g} / \mathrm{mL}$. Patients who needed no more than $2 \mathrm{~g} /$ day of VCM to maintain the $C_{\text {trough }}$ of $\geq 10 \mu \mathrm{g} / \mathrm{mL}$ at steady-state were defined as standard-dose patients.
Patients who needed more than $2 \mathrm{~g} /$ day of VCM (e.g., $1.5 \mathrm{~g}$ every $12 \mathrm{~h}$ or $1 \mathrm{~g}$ every $8 \mathrm{~h}$ ) to maintain the $\mathrm{C}_{\text {trough }}$ of $\geq 10 \mu \mathrm{g} / \mathrm{mL}$ at steady-state were defined as high-dose patients. In this study, steady-state values of $\mathrm{C}_{\text {trough }}$ were considered to be those obtained after VCM administration at the same dosage for more than three days. In cases where the steady state $C_{\text {trough }}$ was not measured and/or was in the subtherapeutic range $(<10 \mu \mathrm{g} / \mathrm{mL})$, $\mathrm{VCM}$ dosages necessary to maintain $\mathrm{C}_{\text {trough }}$ within the therapeutic range $(10-20 \mu \mathrm{g} / \mathrm{mL})$ at steady-state were calculated using Bayesian estimation (BE). Calculations were conducted using the SHIONOGI-VCM-TDM Eedition ver. 2.04 (Shionogi Inc., Japan) software [28], and population PK parameters of VCM reported by Rodvold et al. were used [29].

\section{Decision-tree analysis}

JMP 14.0 software (SAS Institute Inc., NC, USA) was used for the decision tree analysis based on recursive partitioning, to identify the factors predicting high-dose patients. The factors reached statistical significance in the univariate logistic regression analysis were included in the decision tree analysis. The partitioning was stopped when the number of patients in the node reaches $<20$.

\section{Construction and validation of decision flowchart}

Based on the final decision tree derived from the estimation set, a decision flowchart was constructed to identify the patients who needed high-dose VCM $(>2 \mathrm{~g} /$ day, e.g., $1.5 \mathrm{~g}$ every $12 \mathrm{~h}$ or $1 \mathrm{~g}$ every $8 \mathrm{~h}$ ). Subsequently, the decision flowchart was applied to the validation set. The resulting sensitivity, specificity, positive predictive value (PPV), negative predictive value (NPV), positive likelihood ratio (PLR), and negative likelihood ratio (NLR) were calculated.

\section{Statistical analysis}

To compare the characteristics of patients between the estimation set and validation set and between the highdose and standard-dose patients, an unpaired $t$-test or Mann-Whitney $U$-test were used for the continuous variables, whereas a $\chi^{2}$-test were used for the categorical variables.

Univariate and multivariate logistic regression analyses were conducted to identify potential predictive factors for high-dose patients. The factors associated with subtherapeutic $C_{\text {trough }}(\leq 10 \mu \mathrm{g} / \mathrm{mL})$ in previous studies were included in the univariate analysis, and the factors reached statistical significance were employed as possible predictive factors in the decision tree analysis. Simultaneously, factors with $P$ value $<0.1$ in univariate analysis were subjected to a stepwise multivariate logistic regression analysis and the results were compared with those 
obtained in decision tree analysis. To ensure the independence of the explanatory variables found in the univariate analysis, the risk of multicollinearity was checked by examining the Pearson's correlation coefficient between each pair of explanatory variables.

All tests for significance were two-tailed, and a $P$ value of $<0.05$ was considered statistically significant. The statistical analyses in this study were performed using SPSS version 24.0 software (IBM, Armonk, NY) except for the decision tree analysis.

\section{Results}

\section{Characteristics of the patients}

Of the 371 patients who received intravenous VCM during the study period and met the inclusion criteria, 272 patients were eligible for enrollment in the study. Of the 272 patients, 146 patients were assigned to the estimation set (high-dose patients, $n=49$; standard-dose patients, $n=97$ ), and 126 patients were assigned to the validation set (high-dose patients, $n=50$; standard-dose patients, $n=76$ ) (Fig. 1). Table 1 shows the characteristics of the patients assigned to the estimation and validation sets. As shown in Table 1, the characteristics of the patients were similar between the estimation and validation set although $\mathrm{SCr}$ and $\mathrm{eCCr}$ in validation set were significantly higher than in the estimation set. There were no significant differences in age, BW, BMI, days until first TDM, first $C_{\text {trough }}$, clinical department, and suspected infection sites. BE was applied for 59 patients $(40.4 \%)$ in the estimation set and 62 patients $(49.2 \%)$ in the validation set, respectively.

\section{Univariate and multivariate logistic regression analysis}

Table 2 summarizes the characteristics of patients assigned to the estimation set. Significant differences in age, BW, BMI, SCr, and eCCr were observed between the high-dose and standard-dose groups. Because a strong positive correlation $(r=0.842)$ between BW and BMI were observed using the Pearson's correlation test conducted prior to multivariate logistic regression analysis, we entered these two variables into a multivariate logistic regression analysis to check the risk of multicollinearity. The results were similar regardless of whether $\mathrm{BW}$ or BMI were entered into the analysis, and age and $\mathrm{eCCr}$ were independently associated with high-dose patients.

\section{Decision tree analysis}

The final decision tree with three layer is shown in Fig. 2. Among the four factors assessed (age, $\mathrm{BW}, \mathrm{sCr}$, and eCCr), age and eCCr were identified as significant predictive factors and these results are consistent with those of multivariate logistic regression analysis (Table 2). The patients were finally classified into four subgroups (subgroup 1, 3, 5, and 6, Fig. 2) using age and eCCr. JMP software automatically classified patients in the subgroups 1, 3 and 5, 6 as standard-dose and high-dose patients, respectively. The sensitivity, specificity, PPV,

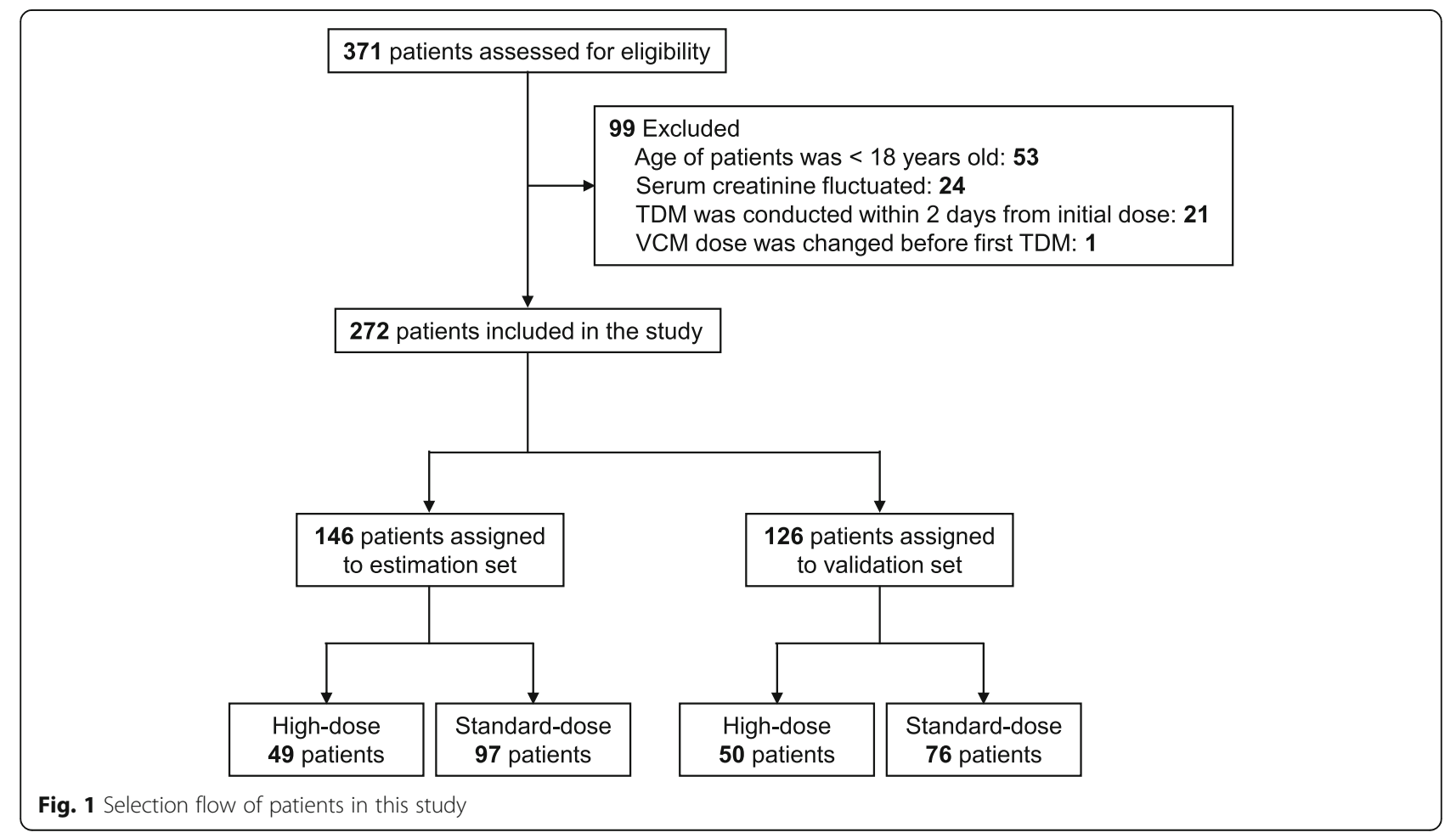


Table 1 Baseline characteristics of patients in estimation and validation set

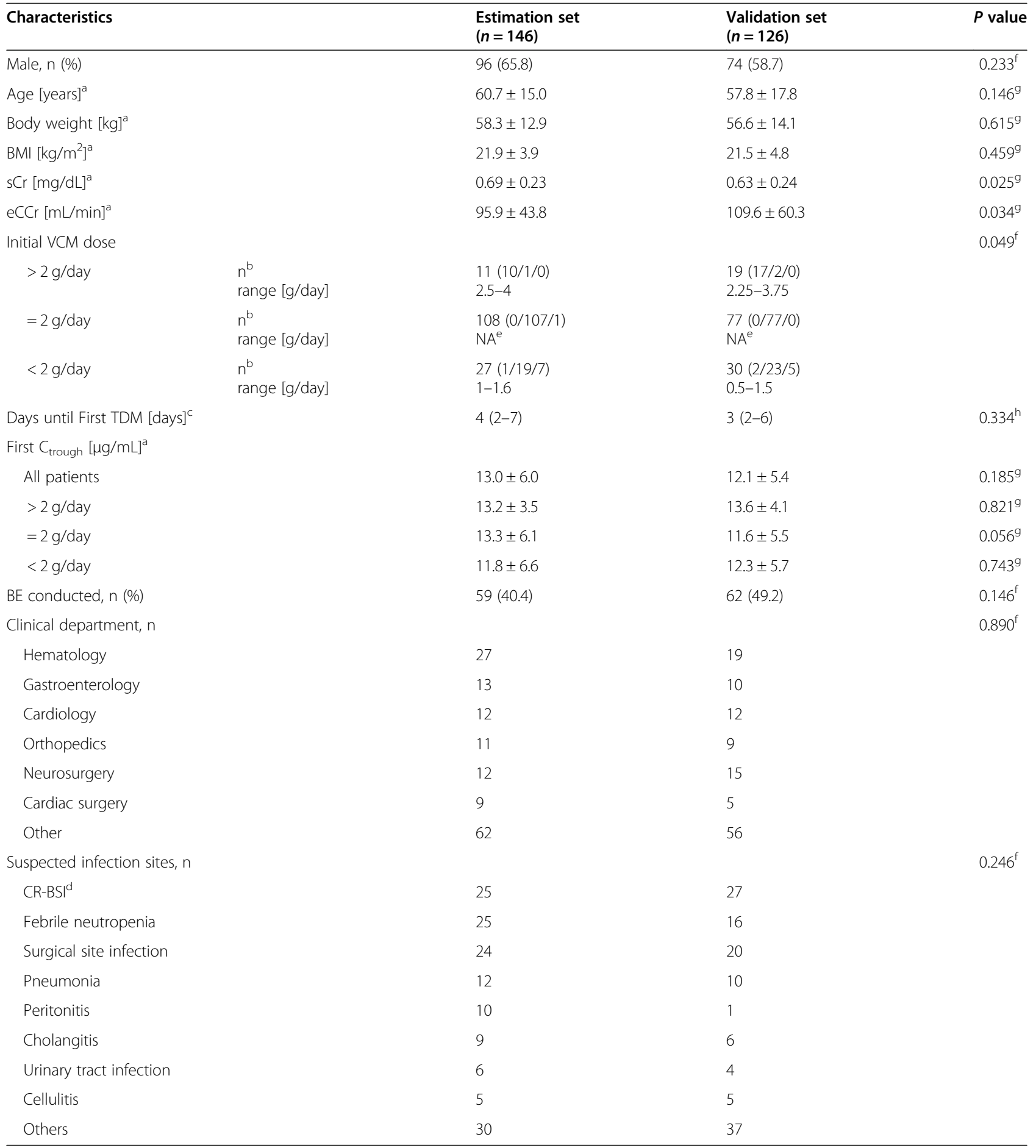

${ }^{\text {aData }}$ are shown as mean \pm standard deviation (SD)

${ }^{b}$ Numbers in parentheses indicate the number of patients with dosing intervals of $8 h, 12 h$, and others from the left, respectively

'Data are shown as median (range)

${ }^{\mathrm{d} C}$ Catheter-related blood stream infection

${ }^{e}$ Not applicable because all patients in $=2 \mathrm{~g}$ /day group uniformly received $2 \mathrm{~g} /$ day of VCM

$\mathrm{X}^{2}$-test

'Unpaired student's $t$-test

${ }^{\mathrm{h}}$ Mann-Whitney U-test 
Table 2 Univariate and multivariate logistic regression analysis in estimation set

\begin{tabular}{|c|c|c|c|c|c|}
\hline \multirow[t]{2}{*}{ Characteristics } & \multirow{2}{*}{$\begin{array}{l}\text { All patients } \\
(n=146)\end{array}$} & \multirow{2}{*}{$\begin{array}{l}\text { High-dose } \\
(n=49)\end{array}$} & \multirow{2}{*}{$\begin{array}{l}\text { Standard- } \\
\text { dose } \\
(n=97)\end{array}$} & \multicolumn{2}{|l|}{$P$ value } \\
\hline & & & & Univariate & Multivariate \\
\hline Male, n (\%) & $96(65.8)$ & $31(63.3)$ & $65(67.0)$ & 0.653 & \\
\hline 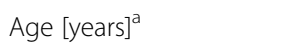 & $60.7 \pm 15.0$ & $52.0 \pm 15.2$ & $65.0 \pm 12.9$ & $<0.001$ & 0.020 \\
\hline Body weight $[\mathrm{kg}]^{\mathrm{a}}$ & $58.3 \pm 12.9$ & $63.1 \pm 13.7$ & $55.8 \pm 11.9$ & 0.002 & - \\
\hline BMI $\left[\mathrm{kg} / \mathrm{m}^{2}\right]^{\mathrm{a}}$ & $21.9 \pm 3.9$ & $23.1 \pm 4.3$ & $21.3 \pm 3.5$ & 0.011 & - \\
\hline $\mathrm{SCr}[\mathrm{mg} / \mathrm{dL}]^{\mathrm{a}}$ & $0.69 \pm 0.23$ & $0.62 \pm 0.19$ & $0.73 \pm 0.24$ & 0.003 & - \\
\hline $\mathrm{eCCr}[\mathrm{mL} / \mathrm{min}]^{\mathrm{a}}$ & $95.9 \pm 43.8$ & $123.0 \pm 40.4$ & $82.2 \pm 38.9$ & $<0.001$ & 0.001 \\
\hline Initial VCM dose, $n^{b}$ & & & & $<0.001^{d}$ & \\
\hline$>2 \mathrm{~g} /$ day & $11(10 / 1 / 0)$ & $11(10 / 1 / 0)$ & $0(0 / 0 / 0)$ & & \\
\hline$=2 \mathrm{~g} /$ day & $108(0 / 107 / 1)$ & $34(0 / 34 / 0)$ & $74(0 / 73 / 1)$ & & \\
\hline$<2$ g/day & $27(1 / 19 / 7)$ & $4(1 / 2 / 1)$ & $23(0 / 17 / 6)$ & & \\
\hline Day until first TDM [days $]^{c}$ & $4(2-7)$ & $3(2-7)$ & $4(3-6)$ & $0.213^{e}$ & \\
\hline \multicolumn{6}{|l|}{ First $C_{\text {trough }}[\mu \mathrm{g} / \mathrm{mL}]^{\mathrm{a}}$} \\
\hline All patients & $13.0 \pm 6.0$ & $8.2 \pm 3.8$ & $15.5 \pm 5.5$ & $<0.001^{f}$ & \\
\hline$>2 \mathrm{~g} /$ day & $13.3 \pm 3.5$ & $13.3 \pm 3.5$ & - & - & \\
\hline$=2 \mathrm{~g} /$ day & $13.3 \pm 6.1$ & $6.8 \pm 2.1$ & $16.3 \pm 4.9$ & $<0.001^{f}$ & \\
\hline$<2 \mathrm{~g} /$ day & $11.8 \pm 6.7$ & $5.8 \pm 3.5$ & $12.8 \pm 6.5$ & $0.047^{f}$ & \\
\hline BE conducted, n (\%) & $59(40.4)$ & $33(67.3)$ & $26(26.8)$ & $<0.001^{d}$ & \\
\hline
\end{tabular}

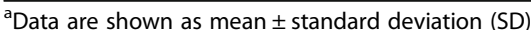

${ }^{\mathrm{b}}$ Numbers in parentheses indicate the number of patients with dosing intervals of $8 \mathrm{~h}, 12 \mathrm{~h}$, and others from the left, respectively

'Data are shown as median (range)

${ }^{d} x^{2}$-test

eMann-Whitney U-test

fUnpaired student's $t$-test

$B M I$ body mass index, $S C r$ serum creatinine, eCCr estimated creatinine clearance, $C_{\text {trough }}$ trough concentration of VCM, $B E$ Bayesian estimation

NPV, PLR, and NLR for estimation set were 69.4, 89.7, 77.3, 85.3\%, 6.74, and 0.34 , respectively (see Additional file 1).

\section{Construction and validation of decision flowchart}

Based on the results of decision tree analysis, we constructed a practical decision flowchart based on eCCr, and age (Fig. 3). In the final decision tree, patients in subgroup 4 (patients with eCCr of $\geq 81.3 \mathrm{~mL} / \mathrm{min}$ and age of $<58$ years) were further split into subgroups 5 and 6 using eCCr of $133.3 \mathrm{~mL} / \mathrm{min}$ as cut off value (Fig. 2 ). However, the decision flowchart did not further split the subgroup 4 because JMP software automatically classified subgroups 5 and 6 as high-dose group.

We then applied the decision flowchart to the validation set. The summary of patients' characteristics in the validation set are presented in Tables 1 and 3. Statistically significant differences were observed in age, BW, $\mathrm{SCr}, \mathrm{CCr}$, and initial VCM dose between high-dose and standard-dose patients within the validation set (Table 3 ), and these observations were similar to those observed within the estimation set. The sensitivity, specificity, PPV, NPV, PLR, and NLR of this decision flowchart for validation set were $76.0,85.5,77.6,84.4 \%, 5.24$, and 0.28 , respectively (see Additional file 1 ).

\section{Discussion}

In this study, we developed a simple decision flowchart based on age and eCCr to predict patients who need high-dose ( $3 \mathrm{~g} /$ day) VCM. When applied to the validation set, this decision flowchart demonstrated successful prediction of patients requiring high-dose VCM to maintain the steady-state $C_{\text {trough }}$ of $\geq 10 \mu \mathrm{g} / \mathrm{mL}$.

In our study population, $38.5 \%(106 / 275)$ of patients were classified as high-dose patients. This observation indicates that a significant proportion of patients with eCCr of greater than $50 \mathrm{~mL} / \mathrm{min}$ are at risk of underdosing (i.e., $C_{\text {trough }}<10 \mu \mathrm{g} / \mathrm{mL}$ ) when treated with a standard dose of VCM ( $2 \mathrm{~g} /$ day). In a previous study, Maki et al. reported that $31 \%$ of patients with eCCr $\geq 50 \mathrm{~mL} /$ min failed to achieve $C_{\text {trough }}$ of $\geq 10 \mu \mathrm{g} / \mathrm{mL}$ after intravenous administration of the standard dose of VCM (2 g/day) [13]. Rosini et al. also reported that approximately $40 \%$ of patients failed to achieve $C_{\text {trough }}$ of $\geq 10 \mu \mathrm{g} / \mathrm{mL}$ $36 \mathrm{~h}$ after an initial intravenously administered VCM dose of $15 \mathrm{mg} / \mathrm{kg}$ every $12 \mathrm{~h}$, which approximates to 2.6 g/day based on an average BW (87 kg) [30]. Similar 


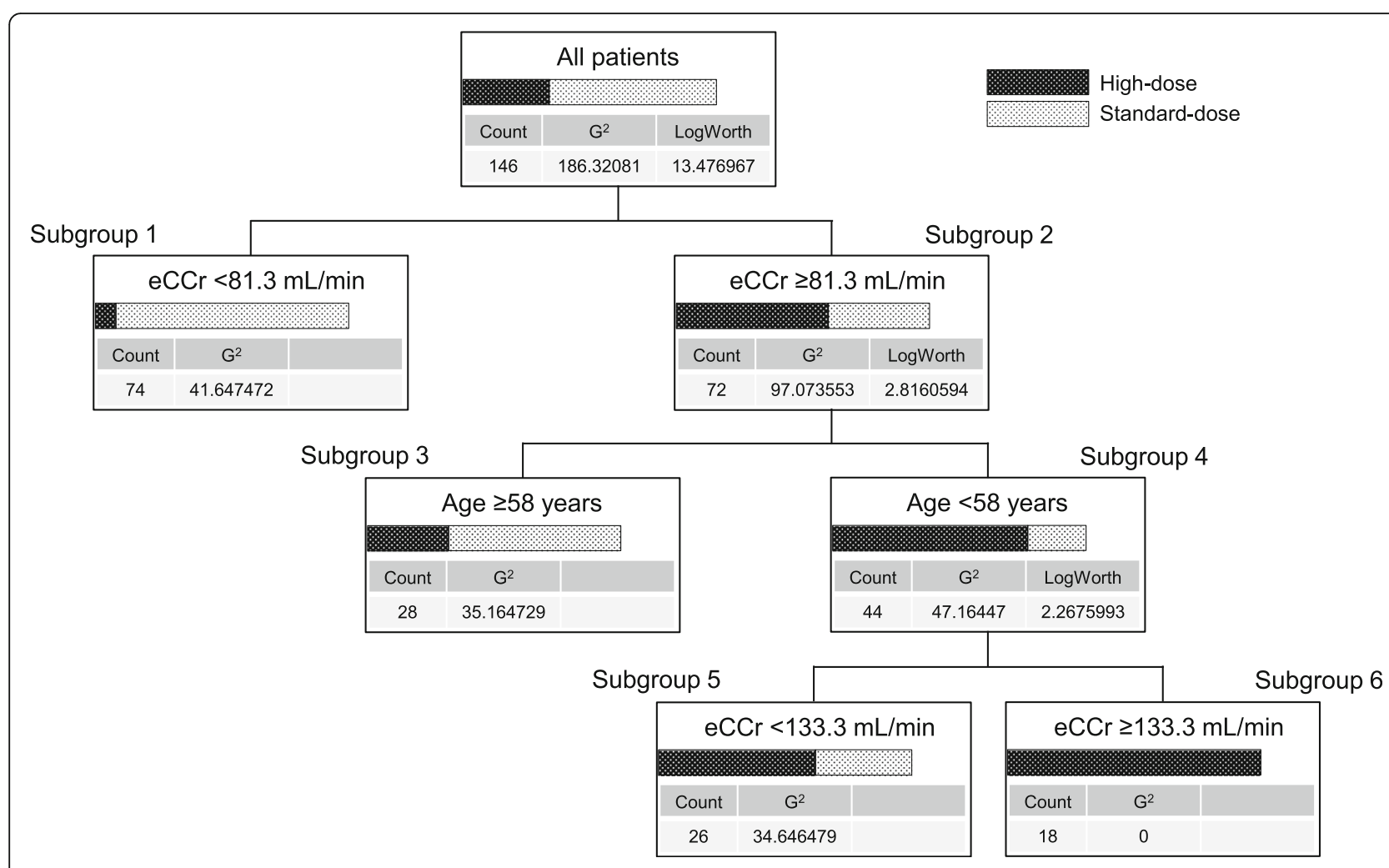

Fig. 2 Final decision tree. Final decision tree with three layer and two predictive factors (age and eCCr) is shown. The cut off value for the split is determined by maximizing the LogWorth. $G^{2}$ value indicates randomness in each subgroup $\left(G^{2}=0\right.$ means perfect fit). The decision tree analysis revealed that eCCr is the top predictive factor and followed by age

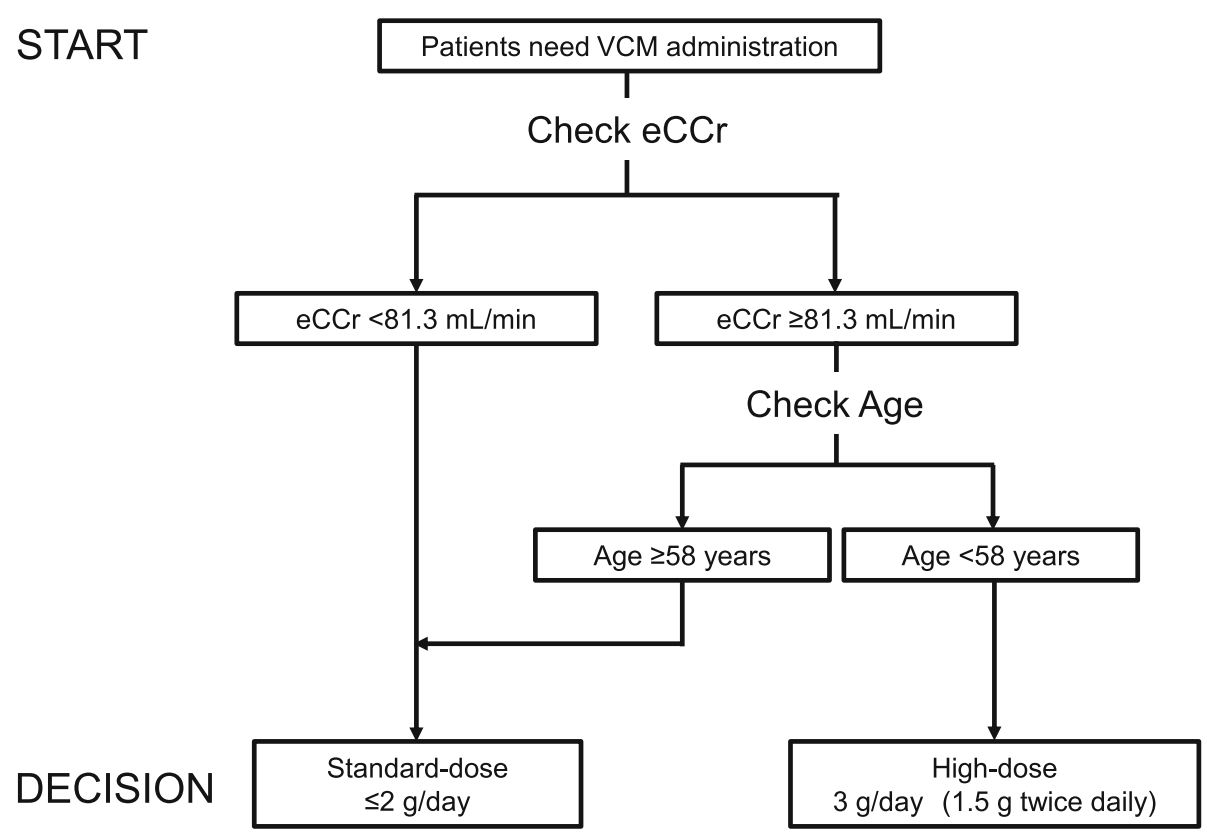

Fig. 3 Decision flowchart for selecting patients who need high-dose VCM. This decision flowchart is constructed to be used for patients with $\mathrm{eCCr}$ of $\geq 50 \mathrm{~mL} / \mathrm{min}$. Patients with age of $<58$ years and eCCr of $81.3-133.3 \mathrm{~mL} / \mathrm{min}$ are at higher risk of overdosing than patients with age of $<$ 58 years and $\mathrm{eCC}$ of $>133.3 \mathrm{~mL} / \mathrm{min}$ when received $3 \mathrm{~g} /$ day of $\mathrm{VCM}$. Thus, for these patients, $2 \mathrm{~g} /$ day of dose may be considered depending on the patient's condition 
Table 3 Characteristics of patients classified in validation set

\begin{tabular}{|c|c|c|c|c|}
\hline Characteristics & $\begin{array}{l}\text { All patients } \\
(n=126)\end{array}$ & $\begin{array}{l}\text { High-dose } \\
(n=50)\end{array}$ & $\begin{array}{l}\text { Standard-dose } \\
(n=76)\end{array}$ & $P$ value \\
\hline Male, n (\%) & $74(58.7)$ & $25(50.0)$ & $49(64.5)$ & $0.331^{d}$ \\
\hline Age $[y e a r s]^{a}$ & $57.8 \pm 17.8$ & $46.5 \pm 14.6$ & $65.1 \pm 15.5$ & $<0.001^{\mathrm{e}}$ \\
\hline Body weight $[\mathrm{kg}]^{\mathrm{a}}$ & $56.6 \pm 14.1$ & $60.8 \pm 15.1$ & $53.9 \pm 12.7$ & $0.009^{e}$ \\
\hline BMI $\left[\mathrm{kg} / \mathrm{m}^{2}\right]^{\mathrm{a}}$ & $21.5 \pm 4.8$ & $22.5 \pm 5.7$ & $20.9 \pm 4.0$ & $0.096^{\mathrm{e}}$ \\
\hline $\mathrm{SCr}[\mathrm{mg} / \mathrm{dL}]^{\mathrm{a}}$ & $0.63 \pm 0.24$ & $0.54 \pm 0.20$ & $0.69 \pm 0.25$ & $<0.001^{\mathrm{e}}$ \\
\hline $\mathrm{eCCr}[\mathrm{mL} / \mathrm{min}]^{a}$ & $109.6 \pm 60.3$ & $145.8 \pm 56.4$ & $85.9 \pm 50.3$ & $<0.001^{\mathrm{e}}$ \\
\hline Initial VCM dose, $\mathrm{n}^{\mathrm{b}}$ & & & & $<0.001^{\circ}$ \\
\hline$>2$ g/day & $19(17 / 2 / 0)$ & $16(14 / 2 / 0)$ & $3(3 / 0 / 0)$ & \\
\hline$=2 \mathrm{~g} /$ day & $77(0 / 77 / 0)$ & $29(0 / 29 / 0)$ & $48(0 / 48 / 0)$ & \\
\hline$<2$ g/day & $30(2 / 23 / 5)$ & $5(1 / 4 / 0)$ & $25(1 / 19 / 5)$ & \\
\hline Days until first TDM [days] ${ }^{c}$ & $3(2-6)$ & $3(3-5)$ & $3(2-6)$ & $0.962^{f}$ \\
\hline \multicolumn{5}{|l|}{ First $C_{\text {trough }}[\mu \mathrm{g} / \mathrm{mL}]^{\mathrm{a}}$} \\
\hline All patients & $12.1 \pm 5.4$ & $8.5 \pm 4.2$ & $14.4 \pm 4.8$ & $<0.001^{\mathrm{e}}$ \\
\hline$>2$ g/day & $13.6 \pm 4.1$ & $13.0 \pm 4.0$ & $16.8 \pm 4.0$ & $0.140^{\mathrm{e}}$ \\
\hline$=2 \mathrm{~g} /$ day & $11.6 \pm 5.5$ & $6.8 \pm 2.1$ & $14.6 \pm 4.8$ & $<0.001^{\mathrm{e}}$ \\
\hline$<2 \mathrm{~g} /$ day & $12.3 \pm 5.7$ & $4.6 \pm 2.1$ & $13.9 \pm 4.9$ & $<0.001^{e}$ \\
\hline BE conducted, n (\%) & $62(49.2)$ & $30(60.0)$ & $32(42.1)$ & $0.049^{d}$ \\
\hline
\end{tabular}

Data are shown as mean \pm standard deviation (SD)

${ }^{b}$ Numbers in parentheses indicate the number of patients with dosing intervals of $8 h, 12 h$, and others from the left, respectively

'Data are shown as median (range)

${ }^{\mathrm{d}} \mathrm{X}^{2}$-test

eUnpaired student's $t$-test

f Mann-Whitney U-test

$B M I$ body mass index, $\mathrm{SCr}$ serum creatinine, $e C C r$ estimated creatinine clearance, $C_{\text {trough }}$ trough concentration of VCM, $B E$ Bayesian estimation

results were observed in a study conducted in patients with eGFR of $\geq 90 \mathrm{~mL} / \mathrm{min} / 1.73 \mathrm{~m}^{2}$ [31]. These results are all consistent with those of the present study and indicate that a large number of patients need high-dose VCM to achieve the $C_{\text {trough }}$ of $\geq 10 \mu \mathrm{g} / \mathrm{mL}$.

There have been several reports indicating a possible relationship between younger age and lower $C_{\text {trough }}$. Revilla et al. reported that only $33.4 \%$ of critically ill patients under 65 years of age and with eCCr of $>60 \mathrm{~mL} /$ min could attain the target $\mathrm{PK} / \mathrm{PD}$ index $\left(\mathrm{AUC}_{24} / \mathrm{MIC}>\right.$ 400) after intravenous administration of $\mathrm{VCM}$ at the dose of $2 \mathrm{~g} /$ day [32]. In addition, Ishii et al. reported that younger age $(<50$ years $)$ was associated with subtherapeutic $C_{\text {trough }}$ after dosage adjustment based on individual eGFR [33]. Interestingly, in our study population, age is a significant predictor only in patients with eCCr $\geq 81.3 \mathrm{~mL} / \mathrm{min}$ (Fig. 2). Although the underlying mechanism of the eCCr-dependent effect of age observed in our study population is unclear, we believe it may be partially attributable to overestimation of renal function in elderly patients with high eCCr. Previous studies have shown that creatinine production tends to decrease owing to loss of muscle mass in elderly patients and consequently, eCCr calculated from SCr tends to overestimate the actual renal function [34]. In elderly patients with eCCr $\geq 81.3 \mathrm{~mL} / \mathrm{min}$, low $\mathrm{SCr}$ could be reflecting loss of muscle mass rather than increased renal excretion; thus, the discrepancy between eCCr and actual renal function in these patients would be larger than that in patients with $\mathrm{eCCr}<81.3 \mathrm{~mL} / \mathrm{min}$.

Although there were some differences in patient characteristics between the estimation set and validation set (Table 1), PPV and NPV were 77.6 and $84.4 \%$ respectively, and these values were comparable to those in the estimation set (69.4 and $89.7 \%$ respectively). This observation seems to support the preferable predictive performance and the robustness of the decision flowchart developed in this study. When the predictive performance in this study is compared with those in previous report by Imai et al. [19], our decision flowchart showed a lower risk of underdosing (10.3\% vs $33.5 \%)$ and a higher risk of overdosing (30.6\% vs $15.8 \%)$. This indicates that our decision flowchart tends to overestimate the dosage compared to the algorithm reported by Imai et al. Although the reason why our decision flowchart tends to overestimate the dosage is unclear, one possible explanation is that patients in subgroup 5 (patients with age of $<58$ years and eCCr of $81.3-133.3 \mathrm{~mL} / \mathrm{min}$ ) were uniformly classified as high-dose patients. When patients classified as subgroup 5 (age $<58$ years, CCr $81-133$ ) 
were judged as standard-dose, the PPV and NPV changed to 86.2 and $74.2 \%$, respectively (see Additional file 1 ). This suggests that about $15 \%$ of patients are at the risk of overdosing, while about $25 \%$ are at the risk of underdosing. These values are similar to those reported by Imai et al., although the risk of underdosing is somewhat lower in our decision flowchart.

Since this study focused on the pharmacokinetic evaluation, we excluded patients with fluctuating renal function from this study. Although there were no patients who were classified as high-dose group based on our decision flowchart and actually received $>2 \mathrm{~g} /$ day of VCM among the excluded patients due to fluctuating renal function (data not shown), the risk of VCM-induced kidney injury remains unclear when our decision flowchart is applied to daily clinical practice. Therefore, careful consideration should be taken to avoid overdosing when applying our decision flowchart to patients receiving VCM, especially those classified in subgroup 5, the subgroup with poor predictivity. As shown in Fig. 2, the proportions of high-dose and standard-dose patients in subgroup 5 are 61.5 and $38.5 \%$, respectively. Therefore, if $3 \mathrm{~g} /$ day of VCM is uniformly selected for patients classified into subgroup 5, approximately $40 \%$ of patients are at the risk of overdosing. This indicate that patients in subgroup 5 (patients with age of $<58$ years and eCCr of $81.3-133.3 \mathrm{~mL} / \mathrm{min}$ ) are at higher risk of overdosing compared to patients in subgroup 6 (patients with age of $<58$ years and eCCr of $>133.3 \mathrm{~mL} / \mathrm{min}$ ). Thus, for patients in subgroup $5,2 \mathrm{~g}$ /day of dose may be considered depending on the patient's condition (e.g., dehydration, concomitant use of calcineurin inhibitors, aminoglycosides, or piperacillin/tazobactam). In addition, because it has been reported that VCM-induced kidney injury tends to occur after the fourth day from initial administration $[35,36]$, the risk of VCM-induced kidney injury would be minimized by performing TDM on the third or fourth day of treatment and adjusting the dosage.

In this study, we defined therapeutic $\mathrm{C}_{\text {trough }}$ as 10 $20 \mu \mathrm{g} / \mathrm{mL}$ based on the previous pharmacokinetic studies [5-7]. However, in the latest IDSA guidelines [4], an aggressive $C_{\text {trough }}(>15 \mu \mathrm{g} / \mathrm{mL})$ is no longer recommended for serious MRSA infections to minimize the risk of nephrotoxicity. In addition, Oda et al. recently reported that the estimated $\mathrm{C}_{\text {trough }}$ needed to maintain the $\mathrm{AUC}_{24}$ at $400-560$ in patients with eGFR of $\geq 60 \mathrm{~mL} / \mathrm{min} / 1.73$ $\mathrm{m}^{2}$ is $9.3-14.8 \mu \mathrm{g} / \mathrm{mL}$ [37]. Taking these recent literatures into consideration, $C_{\text {trough }}$ of $10-15 \mu \mathrm{g} / \mathrm{mL}$ has a demonstrated clinical value as a predictive index of $\mathrm{AUC}_{24} / \mathrm{MIC}$, although $\mathrm{C}_{\text {trough }}$ of $15-20 \mu \mathrm{g} / \mathrm{mL}$ may increase the risk of acute kidney injury and should be avoided. Therefore, careful attention should be paid when interpreting the results of this study in clinical settings. In our study population, the mean $\mathrm{C}_{\text {trough }}$ in high- dose patients at the dose of $2 \mathrm{~g} /$ day was $6.8 \mu \mathrm{g} / \mathrm{mL}$ in both estimation and validation sets. Therefore, we estimate that if the dosage is increased to $3 \mathrm{~g} /$ day, the $\mathrm{C}_{\text {trough }}$ would still be controlled within $10-15 \mu \mathrm{g} / \mathrm{mL}$. For these reasons, $3 \mathrm{~g} /$ day of VCM would be recommended for patients classified as high-dose patient by our decision flowchart (Fig. 3). In routine practice, $1 \mathrm{~g}$ of VCM every $8 \mathrm{~h}$ (thrice a day) or $1.5 \mathrm{~g}$ every $12 \mathrm{~h}$ (twice a day) is the usual dosage regimen to administer $3 \mathrm{~g} /$ day total VCM, considering the ease of administration and the dosage unit of VCM $(0.5 \mathrm{~g} / \mathrm{vial})$. However, based on the principle of pharmacokinetics, twice a day administration $(1.5 \mathrm{~g}$ every $12 \mathrm{~h})$ achieves lower $C_{\text {trough }}$ than thrice a day administration ( $1 \mathrm{~g}$ every $8 \mathrm{~h})$; thus, it seems safer to choose $1.5 \mathrm{~g}$ every $12 \mathrm{~h}$.

There are several limitations to our study. First, this study was a single-center, retrospective, observational study. Therefore, the possible interference of unintentional selection biases may exist; hence, the generalizability of our results should be confirmed in future studies. Second, clinical efficacy and safety were not evaluated in this study. Nevertheless, since the mean $\mathrm{C}_{\text {trough }}$ in high-dose patients $(\mathrm{VCM}>2 \mathrm{~g} /$ day) was below $15 \mu \mathrm{g} / \mathrm{mL}(13.3 \pm 3.5$ and $13.1 \pm 3.9 \mu \mathrm{g} / \mathrm{mL}$ for the estimation and validation sets, respectively (Tables 2,3 ), the risk of nephrotoxicity would be acceptable in clinical settings. Third, sepsis status was not evaluated as a possible predictive factor of subtherapeutic $\mathrm{C}_{\text {trough }}$ in the decision-tree analysis due to the difficulty in diagnosing sepsis from chart review. Therefore, predictive value of sepsis status should be evaluated in future studies. Fourth, BE is applied for half of the patients to discriminate high-dose patients from standard-dose patients. However, considering that only patients with $\mathrm{eCCr} \geq 50$ $\mathrm{mL} / \mathrm{min}$ were included, and the first $C_{\text {trough }}$ was measured at least 3 days after the start of treatment, we believe that the results of $\mathrm{BE}$ are reliable. Fifth, no patients included in this study received loading dose. Although we expect that the decision flowchart is applicable to patients who received loading dose since steady-state $\mathrm{C}_{\text {trough }}$ was utilized in this study, further studies are needed to elucidate whether our results is applicable to patients who received loading dose.

\section{Conclusion}

We developed, and validated a decision flowchart using $\mathrm{eCCr}$ and age to predict which patients would need high-dose VCM ( $3 \mathrm{~g} /$ day, e.g., $1.5 \mathrm{~g}$ every $12 \mathrm{~h})$. This decision flowchart will provide an important contribution for avoiding underdosing of VCM in patients with eCCr of $\geq 50 \mathrm{~mL} / \mathrm{min}$.

\section{Abbreviations}

AIBW: Adjusted ideal body weight; ARC: Augmented renal clearance; AUCROC: Areas under the receiver operating characteristic curve; $\mathrm{UUC}_{24}$ : Area 
under the drug concentration-time curve over 24 h; $\mathrm{AUC}_{24} / \mathrm{MIC}$ : Ratio of area under the drug concentration-time curve over $24 \mathrm{~h}$ to minimum inhibitory concentration of pathogens; BE: Bayesian estimation; BMI: Body mass index; BW: Body weight; CCr: Creatinine clearances; Cl: Confidential interval; $C_{\text {trough: }}$ Trough concentration of vancomycin; eCCr: Estimated creatinine clearance using the Cockcroft-Gault equation; eGFR: Estimated glomerular filtration rate; IBW: Ideal body weight; KDIGO: Kidney Diseaselmproving Global Outcomes; MIC: Minimum inhibitory concentration of pathogens; MRSA: Methicillin-resistant Staphylococcus aureus; NLR: Negative likelihood ratio; NPV: Negative predictive value; PK PD: Pharmacokinetic/pharmacodynamic; PLR: Positive likelihood ratio; PPV: Positive predictive value; ROC: Receiver operating characteristic; SCr: Serum creatinine; VCM: Vancomycin

\section{Supplementary Information}

The online version contains supplementary material available at https://doi. org/10.1186/s40780-021-00231-w.

\section{Additional file 1.}

\section{Acknowledgments}

We greatly appreciate Editage (www.editage.jp) for English language editing.

\section{Authors' contributions}

RY, HK and TY designed the study, collected clinical data, performed data analysis, and wrote the manuscript. TT, and HS participated in developing the study design and drafting the manuscript. All authors have read and approved the final manuscript.

\section{Funding}

This study did not receive funding from any funding source.

\section{Availability of data and materials}

The datasets used and/or analyzed during the current study are available from the corresponding author on reasonable request.

\section{Declarations}

\section{Ethics approval and consent to participants}

The institutional review board of the Graduate School of Medicine and Faculty of Medicine, The University of Tokyo, approved the study protocol (approval number: 2529). The institutional review board granted an opt-out recruitment approach and waived the need for obtaining written informed consent from each patient. The study was carried out in accordance with the Declaration of Helsinki and its latest amendment.

\section{Consent for publication}

Not applicable.

\section{Competing interests}

The authors declare that they have no competing interests.

Received: 20 August 2021 Accepted: 5 November 2021

Published online: 04 January 2022

\section{References}

1. Liu C, Bayer A, Cosgrove SE, Daum RS, Fridkin SK, Gorwitz RJ, et al. Clinical practice guidelines by the infectious diseases society of america for the treatment of methicillin-resistant Staphylococcus aureus infections in adults and children. Clin Infect Dis. 2011;52(3):e18-55. https://doi.org/10.1093/cid/ ciq146.

2. Holmes NE, Turnidge JD, Munckhof WJ, Robinson JO, Korman TM, O'Sullivan MV, et al. Vancomycin AUC/MIC ratio and 30-day mortality in patients with Staphylococcus aureus bacteremia. Antimicrob Agents Chemother. 2013; 57(4):1654-63. https://doi.org/10.1128/AAC.01485-12.

3. Gawronski KM, Goff DA, Brown J, Khadem TM, Bauer KA. A stewardship program's retrospective evaluation of vancomycin AUC24/MIC and time to microbiological clearance in patients with methicillin-resistant
Staphylococcus aureus bacteremia and osteomyelitis. Clin Ther. 2013;35(6) 772-9. https://doi.org/10.1016/j.clinthera.2013.05.008.

4. Rybak MJ, Le J, Lodise TP, Levine DP, Bradley JS, Liu C, et al. Therapeutic monitoring of vancomycin for serious methicillin-resistant Staphylococcus aureus infections: a revised consensus guideline and review by the American Society of Health-System Pharmacists, the Infectious Diseases Society of America, the Pediatric Infectious Diseases Society, and the Society of Infectious Diseases Pharmacists. Am J Health Syst Pharm. 2020;77(11): 835-64. https://doi.org/10.1093/ajhp/zxaa036.

5. Clark L, Skrupky LP, Servais R, Brummitt CF, Dilworth TJ. Examining the relationship between vancomycin area under the concentration time curve and serum trough levels in adults with presumed or documented staphylococcal infections. Ther Drug Monit. 2019;41(4):483-8. https://doi. org/10.1097/FTD.0000000000000622.

6. Bel Kamel A, Bourguignon L, Marcos M, Ducher M, Goutelle S. Is trough concentration of vancomycin predictive of the area under the curve? A clinical study in elderly patients. Ther Drug Monit. 2017:39(1):83-7. https:// doi.org/10.1097/FTD.0000000000000359.

7. Lanke S, YU T, Rower JE, Balch AH, Korgenski EK, Sherwin CM. AUC-guided vancomycin dosing in adolescent patients with suspected Sepsis. J Clin Pharmacol. 2017:57(1):77-84. https://doi.org/10.1002/jcph.782.

8. Lodise TP, Patel N, Lomaestro BM, Rodvold KA, Drusano GL. Relationship between initial vancomycin concentration-time profile and nephrotoxicity among hospitalized patients. Clin Infect Dis. 2009;49(4):507-14. https://doi. org/10.1086/600884

9. Aljefri DM, Avedissian SN, Rhodes NJ, Postelnick MJ, Nguyen K, Scheetz $\mathrm{MH}$. Vancomycin area under the curve and acute kidney injury: a Metaanalysis. Clin Infect Dis. 2019;69(11):1881-7. https://doi.org/10.1093/cid/ ciz051.

10. Tsutsuura M, Moriyama H, Kojima N, Mizukami Y, Tashiro S, Osa S, et al. The monitoring of vancomycin: a systematic review and meta-analyses of area under the concentration-time curve-guided dosing and trough-guided dosing. BMC Infect Dis. 2021;21(1):153. https://doi.org/10.1186/s12879-02105858-6.

11. Matzke GR, Zhanel GG, Guay DR. Clinical pharmacokinetics of vancomycin. Clin Pharmacokinet. 1986;11(4):257-82. https://doi.org/10.2165/00003088-1 98611040-00001.

12. Matsumoto K, Takesue $Y$, Ohmagari N, Mochizuki T, Mikamo H, Seki M, et al. Practice guidelines for therapeutic drug monitoring of vancomycin: a consensus review of the Japanese Society of Chemotherapy and the Japanese Society of Therapeutic Drug Monitoring. J Infect Chemother. 2013; 19(3):365-80. https://doi.org/10.1007/s10156-013-0599-4.

13. Maki N, Ohkuchi A, Tashiro Y, Kim MR, Le M, Sakamoto T, et al. Initial dose of vancomycin based on body weight and creatinine clearance to minimize inadequate trough levels in Japanese adults. Eur J Clin Microbiol Infect Dis. 2012;31(10):2537-43. https://doi.org/10.1007/s10096-012-1593-y.

14. Adnan S, Ratnam S, Kumar S, Paterson D, Lipman J, Roberts J, et al. Select critically ill patients at risk of augmented renal clearance: experience in a Malaysian intensive care unit. Anaesth Intensive Care. 2014;42(6):715-22. https://doi.org/10.1177/0310057X1404200606.

15. Udy AA, Jarrett $P$, Stuart J, Lassig-Smith M, Starr T, Dunlop $R$, et al Determining the mechanisms underlying augmented renal drug clearance in the critically ill: use of exogenous marker compounds. Crit Care. 2014; 18(6):657. https://doi.org/10.1186/s13054-014-0657-z.

16. Shimamoto $Y$, Fukuda T, Tominari S, Fukumoto K, Ueno K, Dong M, et al. Decreased vancomycin clearance in patients with congestive heart failure. Eur J Clin Pharmacol. 2013;69(3):449-57. https://doi.org/10.1007/s00228012-1340-4.

17. Shimamoto Y, Fukuda T, Tanaka K, Komori K, Sadamitsu D. Systemic inflammatory response syndrome criteria and vancomycin dose requirement in patients with sepsis. Intensive Care Med. 2013;39(7):1247-52. https://doi.org/10.1007/s00134-013-2909-9.

18. Yasuhara M, Iga T, Zenda H, Okumura K, Oguma T, Yano Y, et al. Population pharmacokinetics of vancomycin in Japanese adult patients. Ther Drug Monit. 1998;20(2):139-48. https://doi.org/10.1097/00007691-19980400000003.

19. Imai S, Takekuma Y, Miyai T, Sugawara M. A new algorithm optimized for initial dose settings of vancomycin using machine learning. Biol Pharm Bull. 2020;43(1):188-93. https://doi.org/10.1248/bpb.b19-00729.

20. Leu WJ, Liu YC, Wang HW, Chien HY, Liu HP, Lin YM. Evaluation of a vancomycin dosing nomogram in achieving high target trough 
concentrations in Taiwanese patients. Int J Infect Dis. 2012;16(11):e804-10. https://doi.org/10.1016/i.jijid.2012.07.005.

21. Cockcroft DW, Gault MH. Prediction of creatinine clearance from serum creatinine. Nephron. 1976;16(1):31-41. https://doi.org/10.1159/000180580.

22. Martin JH, Norris R, Barras M, Roberts J, Morris R, Doogue M, et al.

Therapeutic monitoring of vancomycin in adult patients: a consensus review of the American Society of Health-System Pharmacists, the Infectious Diseases Society of America, and the society of infectious diseases pharmacists. Clin Biochem Rev. 2010;31(1):21-4.

23. Kourogi Y, Ogata K, Takamura N, Tokunaga J, Setoguchi N, Kai M, et al. Establishment of a new initial dose plan for vancomycin using the generalized linear mixed model. Theor Biol Med Model. 2017;14(1):8. https:// doi.org/10.1186/s12976-017-0054-9.

24. Khwaja A. KDIGO clinical practice guidelines for acute kidney injury. Nephron Clin Pract. 2012:120(4):c179-84. https://doi.org/10.1159/000339789.

25. Demirovic JA, Pai AB, Pai MP. Estimation of creatinine clearance in morbidly obese patients. Am J Health Syst Pharm. 2009;66(7):642-8. https://doi.org/1 0.2146/ajhp080200.

26. Park EJ, Pai MP, Dong T, Zhang J, Ko CW, Lawrence J, et al. The influence of body size descriptors on the estimation of kidney function in normal weight, overweight, obese, and morbidly obese adults. Ann Pharmacother. 2012;46(3):317-28. https://doi.org/10.1345/aph.1Q374.

27. Bouquegneau A, Vidal-Petiot E, Moranne O, Mariat C, Boffa JJ, Vrtovsnik F, et al. Creatinine-based equations for the adjustment of drug dosage in an obese population. Br J Clin Pharmacol. 2016;81(2):349-61. https://doi.org/1 $0.1111 /$ bcp. 12817

28. Okada N, Fushitani S, Azuma M, Nakamura S, Nakamura T, Teraoka K, et al. Clinical evaluation of pharmacist interventions in patients treated with antimethicillin-resistant Staphylococcus aureus agents in a hematological Ward. Biol Pharm Bull. 2016;39(2):295-300. https://doi.org/10.1248/bpb.b15-00774.

29. Rodvold KA, Pryka RD, Garrison M, Rotschafer JC. Evaluation of a twocompartment Bayesian forecasting program for predicting vancomycin concentrations. Ther Drug Monit. 1989;11(3):269-75. https://doi.org/10.1097/ 00007691-198905000-00009.

30. Rosini JM, Laughner J, Levine BJ, Papas MA, Reinhardt JF, Jasani NB. A randomized trial of loading vancomycin in the emergency department. Ann Pharmacother. 2015;49(1):6-13. https://doi.org/10.1177/1060028014556813.

31. Ueda T, Takesue Y, Nakajima K, Ichiki K, Ishikawa K, Takai Y, et al. Vancomycin loading dose is associated with increased early clinical response without attainment of initial target trough concentration at a steady state in patients with methicillin-resistant Staphylococcus aureus infections. J Clin Pharm Ther. 2020;45(4):682-90. https://doi.org/10.1111/ jcpt.13144.

32. Revilla N, Martin-Suarez A, Perez MP, Gonzalez FM. Fernandez de Gatta Mdel M. vancomycin dosing assessment in intensive care unit patients based on a population pharmacokinetic/pharmacodynamic simulation. Br J Clin Pharmacol. 2010;70(2):201-12. https://doi.org/10.1111/j.1365-2125.2010.03 679.x.

33. Ishii H, Hirai K, Sugiyama K, Nakatani E, Kimura M, Itoh K. Validation of a nomogram for achieving target trough concentration of vancomycin: accuracy in patients with augmented renal function. Ther Drug Monit. 2018; 40(6):693-8. https://doi.org/10.1097/FTD.0000000000000562.

34. Cirillo M, Anastasio P, De Santo NG. Relationship of gender, age, and body mass index to errors in predicted kidney function. Nephrol Dial Transplant. 2005;20(9):1791-8. https://doi.org/10.1093/ndt/gfh962.

35. Morales-Alvarez MC. Nephrotoxicity of antimicrobials and antibiotics. Adv Chronic Kidney Dis. 2020;27(1):31-7. https://doi.org/10.1053/j.ackd.2019.08. 001.

36. Pritchard L, Baker C, Leggett J, Sehdev P, Brown A, Bayley KB. Increasing vancomycin serum trough concentrations and incidence of nephrotoxicity. Am J Med. 2010;123(12):1143-9. https://doi.org/10.1016/ j.amjmed.2010.07.025.

37. Oda K, Katanoda T, Hashiguchi Y, Kondo S, Narita Y, Iwamura K, et al. Development and evaluation of a vancomycin dosing nomogram to achieve the target area under the concentration-time curve. A retrospective study. J Infect Chemother. 2020;26(5):444-50. https://doi.org/10.1016/j.jiac.2 019.11.009.

\section{Publisher's Note}

Springer Nature remains neutral with regard to jurisdictional claims in published maps and institutional affiliations.

\section{Ready to submit your research? Choose BMC and benefit from}

- fast, convenient online submission

- thorough peer review by experienced researchers in your field

- rapid publication on acceptance

- support for research data, including large and complex data types

- gold Open Access which fosters wider collaboration and increased citations

- maximum visibility for your research: over $100 \mathrm{M}$ website views per year

At BMC, research is always in progress.

Learn more biomedcentral.com/submissions 